\title{
Persian Studies and the Military in Late Imperial Russia (1863-1917): State Power in the Service of Knowledge?
}

DOI:

10.1080/00210862.2013.836330

\section{Document Version}

Final published version

Link to publication record in Manchester Research Explorer

\section{Citation for published version (APA):}

Volkov, D. V. (2013). Persian Studies and the Military in Late Imperial Russia (1863-1917): State Power in the Service of Knowledge? Iranian Studies, 47(6), 915-32. https://doi.org/10.1080/00210862.2013.836330

\section{Published in:}

Iranian Studies

\section{Citing this paper}

Please note that where the full-text provided on Manchester Research Explorer is the Author Accepted Manuscript or Proof version this may differ from the final Published version. If citing, it is advised that you check and use the publisher's definitive version.

\section{General rights}

Copyright and moral rights for the publications made accessible in the Research Explorer are retained by the authors and/or other copyright owners and it is a condition of accessing publications that users recognise and abide by the legal requirements associated with these rights.

\section{Takedown policy}

If you believe that this document breaches copyright please refer to the University of Manchester's Takedown Procedures [http://man.ac.uk/04Y6Bo] or contact uml.scholarlycommunications@manchester.ac.uk providing relevant details, so we can investigate your claim.

\section{OPEN ACCESS}




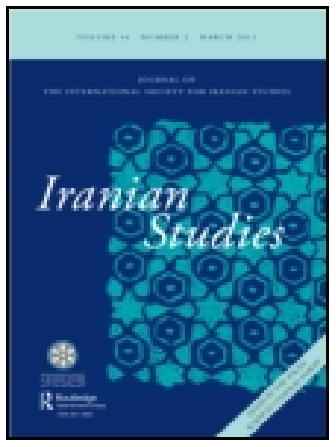

\section{Iranian Studies}

\section{Persian Studies and the Military in Late Imperial Russia (1863-1917): State Power in the Service of Knowledge?}

\section{Denis V. Volkov}

To cite this article: Denis V. Volkov (2014) Persian Studies and the Military in Late Imperial Russia (1863-1917): State Power in the Service of Knowledge?, Iranian Studies, 47:6, 915-932, DOI: $10.1080 / 00210862.2013 .836330$

To link to this article: http://dx.doi.org/10.1080/00210862.2013.836330

册 Published online: 07 Oct 2013.

Submit your article to this journal $\pi$

Џll Article views: 304

Q View related articles $\longleftarrow$

View Crossmark data \lceil

Citing articles: 1 View citing articles 


\section{Persian Studies and the Military in Late Imperial Russia (1863-1917): State Power in the Service of Knowledge?}

This article pursues the goal of going beyond Saidian notions of Orientalism and Said's assumption of the "complicity of knowledge with power" to reach back to Foucault's initial postulations on the role of institutions and the intellectual in the interplay of power/ knowledge relations. The article concentrates on the role of Russian military Oriental studies institutions and Orientologists in the context of discourses (the promotion of Russkoe Delo, the juxtaposition of Russia with the West and the Orient, etc.) that existed in late Imperial Russia and influenced the accumulation and development of scholarly knowledge on the Orient. Therefore, the significant contribution of the military domain to Russian Oriental studies on both the institutional and individual levels are examined from the angle of intra-Russian discourses in the period from the establishment of the Asiatic Section of the General Staff in 1863 up to 1917.

By the late nineteenth and early twentieth centuries Russian Oriental studies had evolved into a well-developed multi-branched system for the production of scholarly knowledge on the Orient. It comprised manifold Orientological scholarly and academic institutions, as well as relevant structures in the Russian military and diplomatic services, and even within the Russian Orthodox Church. All of them were deeply intertwined in terms of both administrative organization and the content and forms of the activities they would carry out. ${ }^{1}$

Denis V. Volkov is a PhD candidate in the School of Arts, Languages and Cultures at the University of Manchester. This article is based on his current $\mathrm{PhD}$ research on Oriental studies and foreign policy in late Imperial Russia and the early USSR: Russian/Soviet 'Iranology' and Russo-Iranian relations (1900-1941). In 2012, the archival research for this project was assisted by BRISMES, BIPS and BASEES. Link to his profile: http://manchester.academia.edu/DenisVolkov

${ }^{1}$ See Michael Kemper, "Integrating Soviet Oriental Studies," in The Heritage of Soviet Oriental Studies, ed. Michael Kemper and Stephan Conermann (London, 2011), 2. See also David van der Oye Schimmelpenninck, "The Imperial Roots of Soviet Orientology," in The Heritage of Soviet Oriental Studies, ed. Michael Kemper (London, 2011), 31-42; Adeeb Khalid, "Russian History and the Debate over Orientalism," Kritika: Explorations in Russian and Eurasian History 1, no. 4 (Fall 2000): 691-9; Vasilii Bartol'd, "Istoriia izucheniia Vostoka v Evrope i Rossii," in his Sochineniia (Moscow, 1977), 9: 418-19; and Vasilii Bartol'd, "Vostok i russkaia nauka," in his Sochineniia, 9: 537-40. 
Most students of Russia agree that the involvement of Russian Imperial Orientologists in power/knowledge relations occurred in four distinct domains of knowledge production in Russia, namely academic scholarship, the military, the diplomatic service and the Orthodox Church's missionary activities. ${ }^{2}$ However, there is no agreement on the issue of the correlation between the Russian case and the very Western Orientalism depicted by Edward Said in his well-known book. ${ }^{3}$ In this on-going debate, scholars such as Adeeb Khalid, referring to the example of Russian missionary Orientologist Nikolai Ostroumov (1846-1930), argue that it is not justified to carve out the Russian case from Said's general notion of Orientalism, while others such as Nathaniel Knight, based on Vasilii Grigor'ev's (1816-81) troubled relations with the state, are inclined to believe in specific features of Russian Orientalism. ${ }^{4}$ Others such as Vera Tolz, engaging more universally with Foucault's notion of discourses and power/ knowledge relations, offer a broader view on the issue than the one presented by Said. Tolz also refers to the legacy of Russian scholar Viktor Rozen (1849-1908) and the activities of his disciples such as Vasilii Bartol'd (1869-1930), Valentin Zhulovskii (1858-1918) and others, and argues that by the turn of the last century "Russian Imperial scholars often focused on the same issues of political, social, and cultural significance of their work which preoccupy historians of European scholarship in the second half of the twentieth century." 5 Thus, one can reason that not only Bartol'd, with his critique of the Western bias towards the historiography of the Orient, but Rozen's whole school anticipated Edward Said's postulations by almost a century, since as early as the end of the nineteenth century they all "were fully aware that the concepts of 'East' and 'West', 'Europe' and 'Asia' were politically, culturally, and socially constructed." ${ }^{6}$ However, there are other researchers, such as Laura Engelstein, who claim that the Foucauldian regime of power/knowledge is not

\footnotetext{
${ }^{2}$ See A.A. Vigasin and A.N. Khokhlov, eds., Istoriia otechestvennogo vostokovedeniia s serediny XIX veka do 1917 goda (Moscow, 1997).

${ }^{3}$ See Edward Said, Orientalism (New York, 1978).

${ }^{4}$ See the debate which took place on the pages of Slavic Review and Kritika: Explorations in Russian and Eurasian History: Nathaniel Knight, "Grigor'ev in Orenburg, 1851-1862: Russian Orientalism in the Service of Empire?," Slavic Review 59, no. 1 (Spring, 2000): 74-100. See also Nathaniel Knight, "On Russian Orientalism: A Response to Adeeb Khalid," Kritika: Explorations in Russian and Eurasian History 1, no. 4 (Fall 2000): 701-15; Khalid, "Russian History"; and Maria Todorova, "Does Russian Orientalism Have a Russian Soul? A Contribution to the Debate between Nathaniel Knight and Adeeb Khalid," Kritika: Explorations in Russian and Eurasian History 1, no. 4 (Fall 2000): 717-27.

${ }^{5}$ Vera Tolz, Russia's Own Orient: The Politics of Identity and Oriental Studies in the Late Imperial and Early Soviet Periods (Oxford, 2011), 19. Vasilii Vladimirovich Bartol'd (1860-1930), Rozen's disciple, professor at St. Petersburg University (1901), member of Russia's Academy of Sciences, secretary of the Russian Committee for the Study of Central and Eastern Asia (1903-18). He authored more than 650 works on Central Asian, Persian and Islamic studies. Valentin Alekseevich Zhukovskii (1858-1918), professor of Persian language and literature and Dean of the Faculty of Oriental Languages of St. Petersburg University. He was an associate member of the Russian Academy of Sciences, head of the Section of Oriental Languages at the Foreign Ministry (1905-18) and also head of the Translation Section at the Foreign Ministry (1915-17). During the 1880s, 1890s, and 1900s he undertook scholarly missions to Persia. He was an active promoter of Oriental studies within scholarly and state institutions.

${ }^{6}$ Tolz, Russia's Own Orient, 21. See also Bartol'd, "Istoriia izucheniia Vostoka," 226-7.
} 
applicable to Russia at all because of the "underdevelopment" of its state and society structures. ${ }^{7}$ Refuting even the very applicability of Foucauldian methodological framework to late Imperial Russia, Engelstein stresses that " [a]lthough Western culture penetrated the empire's official and civic elites, and the model of Western institutions to a large extent shaped the contours of state and social organization, the regime of 'power/knowledge' never came into its own in the Russian context."

Nevertheless, engaging with Said's notion of Orientalism, and further to the debate of its applicability to Russia, it is obvious that in Said's own terms and in the concrete colonial context of late Imperial Russia the power/knowledge nexus is most evident in the military domain. However, as David Schimmelpenninck argues in his profound deconstruction of Russian Orientalism, "military supremacy in Central Asia did not necessarily translate into gloating within the academy about the East's backwardness. Said's Orientalist schema assumes unanimity, a shared view both of Asia and about how to confront it that simply never existed." Although Alexander Morrison, referring to Edward Browne (1862-1926) in his "Applied Orientalism' in British India and Tsarist Turkestan," stresses that "anti-Imperial Orientalists were hardly peculiar to Russia," the Russian case was, in fact, much more sophisticated. ${ }^{10}$ On the other hand, he rightly argues that "whatever their personal views, the knowledge they produced could still be made use of by states for aggressive and conquering purposes." 11 And this is exactly where Said's "proprietary" very narrow application of Foucault finishes and the Foucauldian, mainly, unconscious and unintended interplay of power relations unfolds. With this in mind and conceiving Said's Orientalism to be a particular, rather narrow case of the manifestation of Foucault's much vaster concept of power relations, in this article I deviate from "Orientalism" and its intended sinister "complicity of knowledge with imperial power," and instead return to original sources and engage with Foucault's initial postulates on the role of institutions and the intellectual in the complex interplay of power relations. ${ }^{12}$

Therefore, this article concentrates on the role of Russian military Orientological institutions and Orientologists in the context of discourses which existed in late Imperial Russia and which influenced the accumulation and development of scholarly knowledge on the Orient. This is done by dwelling upon the two underlying discourses which informed the activities of all four Orientological domains, and particularly the Russian military, namely the promotion of Russkoe Delo (the Russian Cause) and the juxtaposition of Russia with the West and the Orient. However, the main purpose of this article is to highlight one of the major components of power $/$ knowledge relations

\footnotetext{
${ }^{7}$ Laura Engelstein, “Combined Underdevelopment: Discipline and the Law in Imperial and Soviet Russia," in Foucault and the Writing of History, ed. Jan Goldstein (Oxford, 1994), 220-36.

${ }^{8}$ Ibid., 225.

${ }^{9}$ David Schimmelpenninck, Russian Orientalism: Asia in the Russian Mind from Peter the Great to the Emigration (New Haven, CT, 2010), 9, 11.

${ }^{10}$ Alexander Morrison, "Applied Orientalism' in British India and Tsarist Turkestan," in Comparative Studies in Society and History 51, no. 3 (2009): 629.

${ }^{11}$ Ibid., 629.

${ }^{12}$ Edward Said, Orientalism (New York, 1995), 342.
} 
which, regardless of various possible moral assessments of eventual outcome, significantly influenced the development of Orientological scholarship in late Imperial Russia, namely the reciprocal productive impact of agents of power that are vested with new capacities during the interplay of these relations. The article examines the momentous contribution of the military domain to Russian Oriental studies at both the institutional and individual level, at a time when the Russian military was a strong factor in Central Asia and the Middle East. In so doing, it retraces the manifestations of those features which, although intrinsic to the Foucauldian notions, are quite often overlooked in the Orientalism debate, namely the reproduction of power itself, which is knowledge. ${ }^{13}$

The article covers the period from the 1860s, a crucial decade for the Russian Empire, to the infamous year of 1917 , and mainly focuses on Persian studies. In actual fact, the foundation of the Nepliuevskii military college in 1825 in Orenburg was the first institutional step undertaken by the Russian military in the direction of establishing training in Oriental languages for officers. The languages taught at the College were Persian, Tatar and Arabic. However, the number of graduates was small and the quality of training was reportedly poor. Later on, in the middle of the nineteenth century, some eminent scholars, such as Professor Aleksandr KazemBek, prepared a series of specific lectures to be read at the General Staff Academy. ${ }^{14}$ However, this did not improve the overall poor level of training, which was characterized by the later reformist War Minister Dmitry Miliutin (1816-1912) in his memoirs as amateurish. He recalled that his fellow officer-students barely managed to dedicate even their spare time to learning Oriental languages, let alone the unattainable luxury of reading the works of their few predecessors, such as Ivan Blaramberg (1800-78) or Ian Vitkevich (1808-39), or academic Orientologists of the time. ${ }^{15}$

The Russian General Staff Academy itself was only founded in 1832 and it took a very long time to establish Oriental studies there that would be tailored to military needs. The professionalization of the army in general started only in the middle of the nineteenth century and it was the changes in the General Staff services that had an enormous impact on Russian policy and practical activities in Asia in the late nineteenth and the early twentieth century. ${ }^{16}$ The General Staff officers working in the Asian Department were part of Russian society and thus they, of course, were inevitably influenced by relevant discourses which were widespread in educated Russian circles in general, and Russia's Oriental studies community in par-

\footnotetext{
${ }^{13}$ See Michel Foucault, "Prison Talk," in Power/Knowledge, ed. C. Gordon (Brighton, 1980), 52. See also Michel Foucault, "Power," in Power, ed. James D. Faubion (New York, 2000), 120; Sara Mills, Michel Foucault (London, 2005), 33; and Tolz, Russia's Own Orient, 70.

${ }^{14}$ See Vigasin and Khokhlov, Istoriia,, 134, 138.

${ }^{15}$ See Alex Marshall, The Russian General Staff and Asia, 1800-1917 (New York, 2006), 28. In this respect, the noticeable engagement of military officers with Russian and, to some extent, with West European scholarship only began at the end of the nineteenth century after the establishment of the Oriental languages officers' courses in 1883 (see Viktor Rozen, "About Edward Browne," ZVORAO 7 (1893): 370-75; see also Vigasin and Khokhlov, Istoriia, 152-6).

${ }^{16}$ See Mikhail Baskhanov, Russkie voennye vostokovedy (Moscow, 2005), 126-7. See also Marshall, General Staff, 5-7.
} 
ticular. ${ }^{17}$ It was during the 1860 s-1870s that, along with the considerable changes in the public life of Russia, the approach towards scholarly knowledge within the military began to change. Therefore, the time span of this article starts twenty years before the establishment of the officers' courses of Oriental languages at the Educational Section of the Russian Ministry for Foreign Affairs in 1863, the year when the crucial reorganization of the General Staff s eastern activities began.

In the second half of the nineteenth century the struggle for influence in the Near and Middle East between the European powers intensified dramatically. Having been defeated by Russia in the wars of 1804-13 and 1826-28 and, due to further developments in its domestic political and economic life, by the end of the century Persia had ceased to be any military threat whatsoever to its "big northern neighbor" and had turned into an arena of diplomatic rivalry, mainly between Russia and Great Britain. This very rivalry, solidly based on two differently nuanced senses of superiority of the two powers towards the object of contest, shaped the nature of Russian-Persian relations during the latter part of the nineteenth and the beginning of the twentieth century. ${ }^{18}$

A reconnaissance mission carried out by staff officers of the Caucasus military district in 1889 reported the extremely low combat readiness of the Persian troops and suggested that any military confrontation with Persia would only occur if the country was to be pulled into the war by other states. Further intelligence, collected ten years later and transferred to the Russian General Staff, confirmed the previous conclusions and noted a further weakening of the Persian military. The only forecast threats were a risk of insurgency and the danger of Persia changing its political course under foreign influence, as well as the possibility that foreign states, especially Britain and the Ottoman Empire, could launch hostile operations from Persian territory. ${ }^{19}$ Thus, the best way to counteract any such threats was deemed to be expansion and strengthening of the Russian presence in the country. Given its immediate proximity to neighboring British India and the Ottoman Empire, its potential as a new trade area, as well as its military weakness, Persia became the "centre of constant fierce economic and political contest between Russia and Great Britain."

In 1897 the Russian War Minister Aleksei Kuropatkin ${ }^{21}$ submitted to Tsar Nicolas II a secret note entitled "About our tasks in Persia," where he pointed out that, strategically, Russia had no need to annex new territories in Persia and, consequently,

\footnotetext{
${ }^{17}$ See Tolz, Orient, 69-79. See also Marshall, General Staff, 9-10.

${ }^{18}$ See Elena Andreeva, Russia and Iran in the Great Game. Travelogues and Orientalism (New York, 2007), 1-2, 5-6, 59. See also Khalid, "Russian History," 691-9; and Liudmila M. Kulagina, Rossiia i Iran (XIX-nachalo XX veka) (Moscow, 2010), 128.

${ }^{19}$ See Marshall, The General Staff, 108-9. See also Nugsar Ter-Oganov, "Persidskaia kazach'ia brigada: period transformatsii (1894-1903 gg.)," Vostok. Afro-aziatskie obshchestva: istoriia i sovremennost', no. 3 (2010): 69-70.

${ }^{20}$ Ter-Oganov, "Persidskaia kazach'ia brigada," 69-70. See also Kulagina, Rossiia i Iran, 128.

${ }^{21}$ General Aleksei Nikolaevich Kuropatkin (1848-1925), an eminent Russian Orientologist (including works on Persia), full member of the Imperial Russian Geographic Society, in different periods served in Turkestan, was head of the Asian Department of the General Staff, head of the Transcaspian Region, war minister, governor-general of Turkestan. In 1895 A. Kuropatkin was sent to Tehran as a special envoy of the tsar at the Persian court. As war minister he took an active part in establishing Tashkent Officers' School of Oriental Languages and the Officers' Faculty at the Oriental Institute (see Russia's Military
} 
was in a favorable position to use this as a bargaining chip in its Western diplomacy by demanding that other states also keep their hands off Persia. ${ }^{22}$ Kuropatkin and Finance Minister Sergei Witte-the architects of Russia's foreign policy in Persiaconsidered it vitally important for Russia to exercise political and economic influence in Persia in order to prevent the use of Persian territory for possible hostile operations against Russia by other states. ${ }^{23}$ Such an approach was eloquently condensed in Nicolas II's personal oral message, delivered to Naser al-Din Shah by Kuropatkin in 1895, that explicitly said: "We intend to, as before, maintain friendly relations with Persia, however, the preservation of such relations will depend on the actions of the Shah himself." ${ }^{24}$ In the meantime, the Persian ruling establishment, having to put up with the fact that the country became a playground for foreign states, resorted to playing their own game, sometimes very successfully playing the rival powers off against each other. ${ }^{25}$

The main feature of Russia's policy in Persia at the turn of the century was massive Russian penetration carried out by versatile means: economic, political and military. Russian economic weakness and non-competitiveness was supposed to be compensated by its political influence and military presence. ${ }^{26}$ This character of Russian involvement in Asia in the nineteenth and the early twentieth centuries predetermined the substantial role which the Russian military played in the development of Oriental studies. At the early stages of its development Russian Oriental studies particularly needed primary material and in this sense the contribution of the military can scarcely be overestimated. Undeniably, many primary source materials such as manuscripts and artifacts were gathered during expeditions, in military terms "reconnaissance operations," which became routine work in the military domain after the 1860 s. $^{27}$

Historical Archive (henceforth RGVIA), f. 970, op. 3, d. 2262 (Kuropatkin's Record of Service), 1. 4848ob. See also Baskhanov, Russkie, 135-6).

${ }^{22}$ See RGVIA, f. 165 “Kuropatkin's Personal Collection,” op. 1, d. 435 (Section on the Foreign Policy toward Persia). See also the Archive of the Foreign Policy of the Russian Empire (further AVPRI), f. "Persian Desk," d. 2308, 1. 115ob.

${ }^{23}$ See the Archive of Orientologists (St. Petersburg Institute of Oriental Manuscripts) (henceforth AV), f.155, op. 1, d. 152 (The Humble Report of Lieutenant-General Kuropatkin on his Trip to Persia in 1895), 1. 26, 35-6. See also Andreeva, Russia and Iran, 5-6; and Kulagina, Rossiia i Iran, 129.

${ }^{24}$ AV, f. 155, op. 1, d. 152 (The Humble Report of Lieutenant-General Kuropatkin on his Trip to Persia in 1895), 1. 1.

${ }^{25}$ See Andreeva, Russia and Iran, 1. See also Saleh M. Aliev, Istoriia Irana. XX vek (Moscow, 2004), 36; and Kulagina, Rossiia i Iran, 128-9.

${ }^{26}$ See N.K. Ter-Oganov, "Zhizn' i deiatel'nost' Konstantina Nikolaevicha Smirnova in K.N. Smirnov," in Zapiski vospitatelia persidskogo shaha (Tel Aviv, 2002), 6. See also Kulagina, Rossiia i Iran, 157; and Vigasin and Khokhlov, Istoriia, 142.

${ }^{27}$ In this sense and in application to Persia, "historical time reading" started from the "acquisition" of the Ardebil collection of manuscripts in December 1828 that was carried out due to the energetic efforts of the Associated Member of the Russian Academy of Sciences Iosip Senkovskii. In 1828, shortly after the Russian troops captured Ardebil, he went there and persuaded General Paskevich to authorize the "relocation" of the collection. It is only later and, one should assume, merely for the sake of propriety, that it was stipulated in the reparation clause of the Turkmanchai Treaty (see Vasilii Bartol'd, "Obzor deiatel'nosti fakul'teta vostochnykh iazykov," in his Sochineniia, 9: 58; Bartol'd, "Istoriia izucheniia Vostoka," 
Indeed, the task of imperial expansion dictated the necessity of intensive activities in various fields, primarily military. Oriental studies as a discipline, dealing with any information about the region of study, greatly benefited from the nature of these activities-collecting all available information that had been stated as part of the Russian military intelligence doctrine in the East since the $1860 \mathrm{s.}^{28}$

The new approach propagated by Dmitry Miliutin, who was in charge of the War Ministry in the period 1861-81, changed the army's view of the place of scholarly and scientific knowledge and became the rich soil that provided the future rapid development of Russian military Oriental studies. ${ }^{29}$ Putting forward his thesis on the necessity of gathering all the information available to officers, Miliutin argued that the study of Russia's Asian neighbors should be comprehensive (not limited to mere technical reconnaissance), with the descriptive component being complemented by analysis. ${ }^{30}$ It was in Miliutin's time that a system of writing graduation papers, similar to preparing a thesis and passing a viva, was introduced for the officers of the Russian General Staff Academy. This later evolved into the preparation of special reports as a result of the officers' one to two years' field work, carried out in the country of study after graduation from the Academy. ${ }^{31}$

Furthermore, the development of Russia's foreign policy in the Middle East and the resulting sharp political confrontation with Britain dictated that serious efforts in this direction were made. In the wake of the Crimean War the main task of the Russian War Ministry was to counteract the British presence in the East. The General Staff took out the dust-laden reports of the old gallant generals such as Blaramberg and Diugamel, who had studied the feasibility of the conquest of Afghanistan and India with the help of the Russian-trained Persian army. Though the projects were refuted as

468. See also Muriel Atkin, "Soviet and Russian Scholarship on Iran," Iranian Studies in Europe and Japan 20, no. 2/4 (1987): 226). It is even openly mentioned on the site of the Russian National Library that "during the first years of the existence of the library [since 1795] the most significant intakes took place due to the success of the Russian Army in wars with Persia and Turkey ... The manuscripts in Persian, Turkish and Arabic amounted to 420 in the result" (http://www.nlr.ru/fonds/manuscripts/east.htm, accessed June 1, 2013). After that the most significant contributions were made by General Simonich, who was Russian minister to Persia after Griboedov, Consul Khanykov, closely connected to the Russian military, and Colonel Tumanskii, who in the wake of his multiple reconnaissance missions to Persia added a considerable number of the Babi manuscripts. On the twists and turns of Alexander Kun's "hunt for manuscripts" see also Morrison's "Applied Orientalism," 637-9.

${ }^{28}$ See RGVIA, f. 400 “The General Staff,” op. 1, d. 228, 1. 1, 3-10 (von-Kaufmann's correspondence with the War Ministry). See also David van der Oye Schimmelpenninck, "Reforming Military Intelligence," in Reforming the Tsar's Army: Military Innovation in Imperial Russia from Peter the Great to the Revolution, ed. David van der Oye Schimmelpenninck and Bruce W. Menning (Washington, DC, 2004), 141-3.

${ }^{29}$ On Miliutin's activities see his memoirs: D.A. Miliutin, Dnevnik. 1876-1878. 1879-1881 (Moscow, 2010). Also see the relevant literature: A.M. Nikolaeff, "Universal Military Service in Russia and Western Europe," The Russian Review 8, no. 2 (April 1949): 117-26; and Bruce W. Menning, Bayonets before Bullets: The Imperial Russian Army, 1861-1914 (Bloomington, IN, 2000).

${ }^{30}$ See Schimmelpenninck, "Reforming Military Intelligence," 141-3. See also Marshall, The General Staff, 21-30; Vigasin and Khokhlov, Istoriia, 135.

${ }^{31}$ See Baskhanov, Russkie, 5-7. See also Marshall, General Staff, 48. 
impracticable, the East, and particularly Persia, received growing attention from the War Ministry. ${ }^{32}$ In 1863, after the merging of the Department of the General Staff and the Depot of Military Topography into the Headquarters of the General Staff, the status of the Asian Section within the new structure became permanent. ${ }^{33}$ Consequently, given the increased need for well-trained officers with comprehensive knowledge of the region, the attitude towards the Orientological training of officers gradually changed. Officers were strongly encouraged to learn Oriental languages: their additional allowance directly depended on their mastering at least threeArabic, Persian and Turkish. ${ }^{34}$ Those who graduated from the officers' Oriental languages courses with merit were guaranteed accelerated career advancement and were usually assigned to the General Staff. ${ }^{35}$ In time, strong linguistic training was supplemented by the complex study of the region, which was later developed into an independent scholarly branch, prakticheskoe vostokovedenie (practical Orientology), by General Andrei Snesarev (1865-1937) and perfected by the Bolsheviks in the 1920s. ${ }^{36}$

The multiple expeditions organized jointly with learned societies or solely by the Asian Department of the General Staff and by the Turkestan Military Region, particularly to Persia and Afghanistan, made an enormous contribution to Oriental studies, in addition to other activities carried out by Russian military officers. ${ }^{37}$ Along with that, Russian Orientological scholarship even benefited from covert military expeditions. For example, in 1901 a Russian officer, Boris L. Tageev, who had an excellent command of Persian, undertook a covert expedition to Kabul and Mazar-e Sharif on his own initiative in the guise of a Tajik pilgrim. ${ }^{38}$ The expedition was sponsored

\footnotetext{
${ }^{32}$ RGVIA, f. 846, op. 16, d. 18296 (A Note to the War Minister), 1. 1ob.-20; d. 18297 (Blaramberg's Analytical Report), 1. 6ob., 12-13. See Vigasin and Khokhlov, Istoriia, 138-9.

${ }^{33}$ See Vigasin and Khokhlov, Istoriia, 139-41.

${ }^{34}$ RGVIA, f.400 (Asian Section of the General Staff), op. 1, d. 3522 (Correspondence of the Head of the General Staff, 1907), 1. 50-52.

${ }^{35}$ On their graduation, Snesarev, Kosagovskii, Smirnov, Tumanskii, Kuropatkin and others received accelerated promotion for their academic excellence (RGVIA, f. 409, op. 2, p/s 338-604 (Snesarev's Record of Service), 1. 3 (02/06/1899); d. 25711, p/s 317686 (Kosagovskii's Record of Service), 1. 70 (29/03/1885); f. 970, op. 3, d. 2262 (Kuropatkin's Record of Service), 1. 40).

${ }^{36} \mathrm{AV}$, f. 115 (A.E. Snesarev's Private Collection), op. 2, d. 50 (Correspondence with General Shvedov, 1905); op. 1, d. 29 (Correspondence with Pavlovich, 1922).

${ }^{37}$ RGVIA, f. 446 (The Military Scholarly Collection), op. 1, d. 52 (The Correspondence of the Russian Imperial Geographic Society with the War Ministry on the organization of scholarly expeditions to Persia, 1903). See also Andreeva, Russia and Iran, 64-7; Vigasin and Khokhlov, Istoriia, 116, 134; and Marshall, General Staff, 9, 144-6.

${ }^{38}$ Boris Leonidovich Tageev (1871-1938) (pseudonym Rostam-Bek), an officer-vostochnik, a scholar and a writer-he had a remarkable destiny, worthy of his epoch: after his military service in Turkestan and Afghanistan and his alleged severance from the Russian army he took part in the Russo-Japanese War of 1904-5 and was taken prisoner by the Japanese in 1904. Having been set free, he did not come back to Russia and had time to serve in the British Army and to work as a Daily Express front-line correspondent during World War I. After the war he struck up a close acquaintance with Henry Ford and worked for his newspaper syndicate, simultaneously cooperating with the weekly Soviet Russia published in the USA. In 1920 he returned to Russia and worked in structures affiliated with the Revolutionary Military Council of the Republic (Revvoensovet) and other state entities, before he was shot in 1938 on the charge, common for that time, of working for foreign intelligence services (see V. Abramov and V. Frolov, "Voennyi
} 
by the Russian Imperial Geographical Society and the Turkestan Military Region's Intelligence Bureau, due to his previous close ties with both, which he had developed during his service in Central Asia in the 1890s. Three years later a book summarizing the substantial scholarly outcome of the expedition was published. ${ }^{39}$ Along with stating the growing military strength of the Afghans and contrasting the positive changes which were taking place in Afghanistan with the further deterioration in Persia, Tageev tried to be objective in his scholarly articles and books. Demonstrating a rather respectful and, which is more important, understanding approach, his writings also lacked the arrogance of "Europeans"-stepping on the soil of backward or even barbaric Asia-although this sense was also inherent in some other Russian officers of the time. ${ }^{40}$

Another sound example of the contribution of Russian military Persian studies can be found in the activities of a military scholar who was among the first graduates of the courses-Aleksandr Tumanskii (1861-1920), Rozen's disciple, later a major-general and a prominent scholar in Persian, Turkish and Arabic and the main expert of his time on Babism. ${ }^{41}$ The would-be coryphaeus of Soviet Orientology, Krachkovskii, mentioned him as "an Orientologist by vocation, not by profession." ${ }^{42}$ In 1894, Tumanskii was sent on a reconnaissance mission from the southern Caspian coast through the whole of Persian territory, right down to the Persian Gulf. At the

uchenyi-vostokoved Tageev. Ob'ezdil polmira, a rasstrelian v Moskve," Voenno-istoricheskii zhurnal 4 (2002): 77-80. See also Baskhanov, Russkie, 231-2; and Marshall, General Staff, 145-6, 227).

${ }^{39}$ See Boris Tageev, Po Afganistanu. Prikliucheniia russkogo puteshestvennika (Moscow, 1904). The book contained scholarly information on geography and ethnology of mainly Afghanistan in 160 pages and was preceded by a series of articles in restricted journals Razvedchik and Voennyi al'manakh of the War Ministry that also included the military outcomes of the expedition.

${ }^{40}$ In this respect a very useful and interesting study was carried out by Elena Andreeva in Russia and Iran in the Great Game. However, the genre of travelogues that became the selective basis for the works analyzed in the book, formed a community of people the bulk of whom had been extremely little (or not at all) familiar with Persia before visiting it and this Orientological illiteracy predetermined their negative attitudes toward it. The works of such authors were not regarded as valuable contribution and were heavily criticized by Russian scholarship, as was, for example, the case of Evgenii Belozerskii whom Andreeva frequently referred to (pp. 78, 86, 92, 104, 109, 110, 121, 129, 139, 154, 163-4). Suffice it to mention Belozerskii's statement about the "inner emptiness" of the Iranians in comparison to the Europeans who had a "rich individual psychological life." On the criticism of Belozerskii's activities in Persia and of his writings see Valentin Zhukovskii's manuscript (AV, f. 17 (V.A. Zhukovskii), op. 1, d. 24 (Review of Belozerskii's Report)).

${ }^{41}$ In this respect, Tumanskii's eagerness to go in for Persian studies is worth noting. He was admitted to the Academy in 1884 but was expelled in 1985 because of his failure in the translation exam. In 1887 he again tried to pass the entrance exams but was not admitted because of the lack of places. Finally, he succeeded in entering the Academy in 1988. He graduated in 1891 with merit and was assigned to the General Staff. Given his scholarly achievements, in 1911 he was appointed head of the Tiflis Officers' School of Oriental Languages (see RGVIA, f. 409, op. 1, d. 172812, p/s 148-610 (Tumanskii's Record of Service), 1. 18-20ob).

${ }^{42}$ See Baskhanov, Russkie, 242. Ignatii Iulianovich Krachkovskii (1883-1951), professor of Arabic studies (1918). He was a member of the Russian Academy of Sciences (1921) and knew Arabic, Persian and Turkish. In the 1920s he produced a translation of the Qur'an that remained the only reputable one throughout the whole Soviet period. 
same time, he obtained a number of valuable documents and manuscripts on the Babi sect, which he made available to his teachers. In 1908 and 1909 he continued visiting Persia on missions, also using the visits for his scholarly activities.

The fact that he actively participated in activities of the Eastern section of the Russian Imperial Archaeological Society supports the thesis of the deep interconnectedness of all Russian Oriental studies institutions. Significantly contributing to the relevant knowledge production, Tumanskii left multiple works on the history and economy of Persia and a series of works on Babism and translations of key Babi texts, including Ketab-e aghdas. ${ }^{43} \mathrm{He}$ also discovered and translated a tenth century manuscript of the Hodud-ol-alam, which immediately became the object of study by civil scholars. ${ }^{44}$

Indeed, throughout the second half of the nineteenth century, war operations and military reconnaissance expeditions remained the main, if not almost the only, sources for obtaining information on Oriental countries. In his review of the main sources of scholarly information for the study of Iran that were available for Russian scholars in the late nineteenth and the early twentieth centuries, Bartol'd wrote:

A significant amount of information on the economic life of Iran in present and recent past could be found ... in the editions of a "secret" (in reality there were no state secrets) collection "Sbornik geograficheskikh, topograficheskikh i statisticheskikh materialov po Azii" which started to be published in the 1870s. As a matter of fact, the depiction of A.G. Tumanskii's expedition "From the Caspian sea to the Hormoz strait and backward" (1894) was included in the edition, published in $1896{ }^{45}$

Bartol'd also separately pointed out the scholarly importance of the travelogues which would be composed on the basis of such expeditions, even after the censorship of sensitive political and military aspects, with the aim of release to a wider readership. ${ }^{46}$ Analyzing the then state of Oriental studies, and acknowledging the direct beneficial correlation of these activities, pursuing state interests and institutionalized Oriental studies, as early as 1905 Bartol'd wrote that the study of the Middle East had very often only been possible due to colonial wars. ${ }^{47}$ So it

\footnotetext{
${ }^{43}$ See Aleksandr Tumanskii, Kitabe Akdes. Sviashennaia kniga souremennykb babidov (St. Petersburg, 1899).

${ }^{44}$ In 1897 Bartol'd separately mentioned the great impact of this discovery and Tumanskii's translation (see Vasilii Bartol'd, Otchet o poezdke $v$ Sredniuiu Aziiu s nauchnoi tsel'iu, 1893-1894 (St. Petersburg, 1897), 3-4). However, it was published due to Professor Bartol'd's efforts only in Soviet times, in 1930. In 1937, Vladimir Minorskii, then a professor of Persian Studies at the University of London (SOAS), but in the early twentieth century Tumanskii's colleague in the Russian diplomatic service, made an English annotated translation of the manuscript (AV, f. 134, op. 2, d. 116 (Minorskii's private notes on the translation, dated September 26, 1937), 1. 1-2).

${ }^{45}$ Vasilii Bartol'd, "Iran. Istoricheskii obzor," in his Sochineniia, 7: 330.

${ }^{46}$ Ibid.

${ }^{47}$ See Bartol'd, "Istoriia izucheniia Vostoka," 467. See also Vigasin and Khokhlov, Istoriia, 139-41; and Marshall, General Staff, 26.
} 
appears that intellectuals and institutions involved in military activities acted as agents of power in this particular case of interaction between Russia and the Orient, and it suggests that the more capacities with which they were endowed, the greater was their reciprocal productive impact.

From the correspondence between the Ministry for Foreign Affairs and the War Ministry of the time, it is evident that by establishing the Cossack Brigade in Persia in 1879, according to Nasir al-Din Shah's request, Russia was aiming exclusively at enhancing its own influence over the shah's court, as well as preventing other European powers such as Britain from taking a similar step. ${ }^{48}$ However, the shah's Cossack Brigade gradually turned into a highly efficient and self-contained Orientological institution, especially during the tenure of Colonel Vladimir Kosagovskii (1894-1903). ${ }^{49}$ All Russian officer-instructors were supposed to compose scholarly reports on virtually all aspects of Persian life: politics, economy, culture, ethnography, geography, linguistics, etc. The officer-candidates posted to Persia were selected by the General Headquarters of the Caucasian Region and the Military Learned Committee of the War Ministry, exclusively from the officers of the General Staff and strictly based on their scholarly merits in Persian studies. ${ }^{50}$ In 1900 , the war minister separately mentioned the Cossack Brigade as a factor allowing Russia, to a great extent, to govern developments in Tehran. ${ }^{51}$ Kuropatkin's words explicitly indicate the impact of the Cossack Brigade and of Colonel Kosagovskii's activities on imperial Russia's foreign policy towards Persia. Being guided by his personal interest in the study of Persia and his perception of promoting Russian interests, Kosagovskii succeeded in occupying an influential place in the Persian political establishment and, in fact, taking advantage of this situation, turned the Cossack Brigade into a powerful tool of Russian political influence in Persia as well as into an abundant source of Orientological information. Cossack officers were constantly on missions in various places in Persia, gathering intelligence which, according to Miliutin, was to comprise information of any

\footnotetext{
${ }^{48}$ RGVIA, f. 446, op. 1, d. 47, 1. 27-30 (Deputy Minister for Foreign Affairs to the Head of the General Staff, 11/03/1894). See also Andreeva, Russia and Iran, 63.

${ }^{49}$ Vladimir Andreevich Kosagovskii (1857-1918), lieutenant-general. Between 1894 and 1903 he was the chief-commander of the Persian Cossack Brigade and 1905-8 he served as head of the Transcaspian region. $\mathrm{He}$ is the author of multiple works on economy, finance, governmental set-up, history, geography, military forces of Persia. He retired in 1909 and lived on his private country estate. After 1917 he had to resort to farming, and after the October Revolution the Bolsheviks burdened him, a "class-alienated landowner," with extremely high taxes, which would have bankrupted him had they not been voluntarily paid by the peasant population of five neighboring villages as a mark of respect towards their former landlord. They also saved him several times from being arrested by the Bolsheviks, but he was finally executed in 1918. His Persian diaries are kept in RGVIA, Collection 76 (Kosagovskii's collection), op. 1, d. 217 (1899-1909), 1. 1-417 (see also Baskhanov, Russkie, 126-7; and Ter-Oganov, "Persidskaia kazach'ia brigada," 69-79.)

${ }^{50}$ RGVIA, f. 446, op. 1, d. 47 (Correspondence between the Head of the Caucasian Military District and the Head of the General Staff, February 4, 1894), 1. 6-8, 1. 10.

${ }^{51}$ AVPRI, f. “Persian Desk," d. 2308 (Kuropatkin's correspondence, 1900), 1. 117.
} 
kind. $^{52}$ The officers' reports would include descriptions of towns, villages, routes, local communities, linguistic specificities, customs and traditions, everyday life, etc. $^{53}$

Throughout the nineteenth century the War Ministry was still entirely dependent on the Ministry for Foreign Affairs in the field of the Orientological training of its officers. It was only in 1883 that the War Ministry succeeded in accomplishing what had been demanded by Miliutin: dedicated courses in the Oriental languages aimed only at officers under the auspices of the Section of Oriental Languages at the Ministry for Foreign Affairs. The curriculum comprised the three main Oriental languages of the time: Persian, Turkish and Arabic. That was also characteristic of the Section itself and the priorities that were being pursued by the Faculty of Oriental Languages of the University of St. Petersburg and Lazarev's Institute of Oriental Languages in Moscow. This reflected the main trends within Russia's foreign policy in the second half of the nineteenth century: military confrontation with the Ottoman Empire and, more importantly, the turf war (or the Great Game) with Britain in Asia. ${ }^{54}$

Besides Oriental languages, students were taught Islamic and international law, French and, after 1907-the year when Russia and Britain became virtual allies after signing the Convention on Persia, Afghanistan and Tibet-also English. In general, there was little difference in terms of the academic content of the dedicated officers' courses in comparison with the curriculum of the civilian students, because the former had been designed by the same academics who taught Oriental studies at the St. Petersburg Faculty of Oriental Languages, which is highly illustrative of the influence of scholarly institutions and practices, if not of the scholars themselves, on state power. In fact, the courses were even run by them. For instance, Valentin Zhukovskii, one of the main scholars in the field of Persian linguistics of the time, who was the dean of the Faculty of Oriental Languages at the University of St. Petersburg, was also the director and lecturer of the officers' courses. ${ }^{55}$

Having barely emerged as a narrowly profiled domain of utilitarian knowledge in the first half of the nineteenth century, by World War I, Russian Military Oriental studies had evolved into an organizationally structured self-contained branch of scho-

\footnotetext{
${ }^{52}$ Though the Soviet and present-day historiography, for unknown reasons, prefer to spell Kosagovskii with "o" in the middle and an established expert on the Persian Cossack Brigade, Nugzar Ter-Oganov, does the same, I adhere to the way Kosagovskii himself would write his name, and so did his direct commander, head of the Caucasian Military District, General Sergei Sheremetev (for example, RGVIA, f. 446, op. 1, d. 47, 1. 6-8, 44). The same spelling with "a" is also adopted in Baskhanov's Russkie voennye vostokovedy (pp. 126-7).

${ }^{53}$ RGVIA, f. 76 (Kosagovskii's Reports to the Military Learned Committee), op. 1, d. 48 (General Report on Trips around Persia and Kurdistan); d. 255 and 256 (Officers' Reports). Delo 254 (1901) demonstrates that Kosagovskii used to entrust even native agents with composing reports on the local life in their towns and villages.

${ }^{54}$ See Richard N. Frye, "Oriental Studies in Russia," in Russia and Asia. Essays on the Influence of Russia on the Asian Peoples, ed. Wayne S. Vucinich (Stanford, CA, 1972), 43-4. See also Marshall, General Staff, 30, 43-5; Vigasin and Khokhlov, Istoriia, 137-41.

${ }^{55}$ See Vasilii V. Bartol'd, "Pamiati V.A. Zhukovskogo," in his Sochineniia, 9: 689. See also Bartol'd, "Istoriia izucheniia Vostoka," 472; Vigasin and Khokhlov, Istoriia, 128; Marshall, General Staff, 17.
} 
larly and practical knowledge, making significant contributions to the development of adjacent fields of general scholarly knowledge. It also appears that the close institutional interconnectedness between the military and civilian (i.e. academic) domains resulted in the very dynamic, interrelated development of both utilitarian and scholarly knowledge. As is clear from the above, senior military officers were members of various Orientological societies, using their activities to effect scholarly outcomes; in addition, prominent Russian scholars of Persian studies, for instance Kazem-Bek, Rozen, Bartol'd, Zhukovskii and others, had strong ties with the military and played the main role in the Oriental training of officers. ${ }^{56}$

This close interconnectedness makes it difficult to classify "civilian" scholars within the four-part institutional typology of Oriental studies in late Imperial Russia. For instance, it is possible to suggest that Zhukovskii belonged to the practical (i.e. diplomatic) domain, rather than the academic domain, since he was so intensely involved in the activities of the Ministry for Foreign Affairs. ${ }^{57}$ Another similar example is a zoologist and geographer Zarudnyi, who might be better placed in the military domain because of his substantial service record at the Russian War Ministry and his multiple expeditions, undertaken in the interests of the same ministry. ${ }^{58}$ The activities of others such as Grigor'ev and Ostroumov may even suggest the existence of a fifth domain, namely Oriental studies of late Imperial Russia's "colonial" administration. However, given the academic training that all the above-mentioned received, their own perception of themselves and their overall activities, as well as the fact that none of them had military or civil service ranking, all these individuals should be categorized within the "civilian" scholarly domain, with the obvious exception of Ostroumov, who rightfully belongs to the Orthodox church missionary domain by his clerical training, the character of his major activities and the content of his works. ${ }^{59}$ In addition, Russian inland "colonial" administration cannot be regarded as an organizationally self-contained domain since it was mainly staffed and managed by military personnel and was completely military in nature. Therefore, the organizational four-domain division, comprising "civilian" academic scholarship, diplomatic service, the military and the Orthodox Church, is applicable to all Russian Oriental studies throughout the whole period from the mid-nineteenth century to 1917 .

Simultaneously, there were obvious strong discursive components in the activities of institutions and individuals, which consisted of the dichotomy of the promotion of Russkoe Delo, which implied the protection of the expansionist goals of the Imperial state in the Orient against Western powers, as well as in the civilizing role of Russia in

\footnotetext{
${ }^{56}$ See Bartol'd, “Istoriia izucheniia Vostoka," 446. See also Marshall, General Staff, 24, 164-5, 168; Vigasin and Khokhlov, Istoriia, 128-9.

${ }^{57}$ See Bartol'd, "Pamiati Zhukovskogo," 700-701.

${ }^{58}$ On Zarudnyi's activities in Russia's War Ministry see RGVIA, f. 446 (correspondence on expeditions to Persia), d. 552 (1903). See also Bartol'd, "Istoriia izucheniia Vostoka," 469-70.

${ }^{59}$ On Ostroumov's activities see Robert Geraci, Window on the East: National and Imperial Identities in Late Tsarist Russia (New York, 2001), 47-115, 223-63. See also Robert Geraci and Michael Khodarkovsky, eds., Of Religion and Empire: Missions, Conversions, and Tolerance in Tsarist Russia (New York, 2001).
} 
the Orient which was stipulated by Russia's alleged affiliation with the European civilization. ${ }^{60}$ However, with regard to the state entities, particularly the Russian military, whose vocation was to protect and promote Russia's state interests, manifestations of this kind should naturally be regarded as inherent and were less sophisticated in terms of existing discourses than, for example, in the "civilian" (academic) scholarly domain. $^{61}$

Given the fact that the discourse of Russkoe Delo emphasized the protection of Russian political and military interests in Persia versus other European powers, particularly Britain, and following the strong belief of their superiority towards Persians, it is not surprising that few Russians were concerned by the detrimental effects of this rivalry on Persia itself. For instance, since 1873, the Russians had been hampering the construction of railways in Persia by every means available because of their fear that the much more economically and industrially developed British and Germans could quickly build railways that would facilitate their take-over of the Persian market and allow them to quickly redeploy their troops on Russia's borders. In 1887, under Russian diplomatic pressure, the Persian government juridically committed itself to refrain from constructing railways and granting relevant concessions. In 1890, Russia and Britain officially signed an agreement regarding the non-construction of railways in Persia, which was renewed in 1900 for other ten years. ${ }^{62}$

As far as the civilizing mission is concerned, much supporting evidence for this can be found in Colonel Kosagovskii's Persian diaries, where he describes his task as one of making the indigenous "semi-wild population" familiar with the Russian way of life; or preventing Russian officers and their units from taking part in the punitive actions of the "Asiatic" Persian government towards its own people during bread riots, thereby stressing the "Christian-like humane" and "truly civilized" character of the Russian mission. ${ }^{63}$ Similar attitudes could be also found in Staff-Captain Konstantin Smirnov's reports of his activities at the shah's court, and in his correspondence with the Russian minister to Persia, Gartvig. ${ }^{64}$ Even such a highly educated, tactful

\footnotetext{
${ }^{60}$ See Khalid, "Russian History," 691-9. See also Knight, "Response to Khalid," 701-15. It should be mentioned that the cultural civilizing of Persians, namely the inculcation of European civilized mentality, was meant to be done with a simultaneous strong emphasis on the Russian cultural and political component (see Vera Tolz, "Imperial Scholars and Minority Nationalisms in Late Imperial and Early Soviet Russia," Kritika: Explorations in Russian and Eurasian History 10, no. 2 (Spring 2009): 268).

${ }^{61}$ The Foucauldian capability of "civilian" scholars, using the capacities, emanated from state, to benefit from state interests by means of creating discourses, necessary for pursuing their own interests, often aimed at the institutional advancement of their scholarly field, was also studied in Krementsov's work, though mostly for the early Soviet period (see Mills, Foucault, 33, 58. See also Nikolai Krementsov, Stalinist Science (Princeton, NJ, 1997), 4-5, 29-30).

${ }^{62}$ See Dietrich Geyer, Russian Imperialism. The Interaction of Domestic and Foreign Policy, 1860-1914 (Hamburg, 1987), 334-5. See also Kulagina, Rossiia i Iran, 132-6; Aliev, Istoriia Irana, 46; and Shirokorad, Rossiia-Angliia: neizvestnaia voina, 1857-1907 (Moscow, 2003), 402.

${ }^{63}$ RGVIA, f. 400, op. 4, d. 279, 1. 9-10 as quoted in Ter-Oganov, "Persidskaia kazach'ia brigada," 76-7.

${ }^{64}$ The Georgian National Centre of Manuscripts (henceforth GNCM), f. 39 "Konstantin Nikolaevich Smirnov," d. 78, "Gartvig's letter to Smirnov," dated August 2, 1909, with Smirnov's later remarks, dated
} 
and Persophile officer as Smirnov quite often allowed himself in his notes to describe himself and other Russians as "civilized in a European manner, in contrast to the "barbarous" and "wild" deeds and traditions he witnessed at the Persian court. ${ }^{65}$ His diaries for 1909 also contain a noteworthy depiction of a successful intelligence micro-operation, aimed at "civilizing andarun in the interests of Russia," which he solely designed and perpetrated. It resulted in "planting" a Russian Muslim governess in the andarun of the shah's court who was supposed to cultivate European customs among women of the court and, simultaneously, to promote all things Russian. ${ }^{66}$ However, there were other officers who fit Said's classical mold of an "Orientalist," such as Captain Belozersky, who wrote bluntly denigrating and insulting notes on the Persian culture and people (published in 1887) after his intelligence mission. This is, though, explained by his poor Persian and his Orientological illiteracy, as he trained only for three months in the Lazarev Institute before he traveled to Persia and he was not an officer-vostochnik. As a rule, such people had influence neither in the Asian Section of the General Staff nor in scholarly circles. After its publication in 1887, his book suffered heavy criticism from Russia's Persian studies scholarship. ${ }^{67}$ Against the backdrop of this compound of exclusive and inclusive discursive components it is easy to discern the constant endeavors of Russian officers to position themselves closer to the "civilized part of the world". The more Iranians were perceived as wild and underdeveloped, the more officers perceived themselves as civilizing, full-fledged Europeans, as though supporting Dostoevskii's thesis that Russians were Europeans in Asia and Tatars in Europe. ${ }^{68}$

Christianity was another factor which always underpinned Russian "Europeanness" and also impacted on officers' self-perception in the Orient. Russian officers could hardly conceal their empathy with Persian Armenians and Assyrians in their activities and judgments. In his regular reports addressed to the Military Learned Committee of the War Ministry, Colonel Kosagovskii would sincerely express his moral shock when depicting atrocities perpetrated by Turks and Kurds

1933. See also Konstantin Smirnov, Zapiski vospitatelia persidskogo shaha (Tel Aviv, 2002). Military Orientologist, Colonel Konstantin Nikolaevich Smirnov (1877-1938) authored a considerable number of works on Persian history, ethnography, geography and economy. Having graduated from the officers' courses of Oriental languages he served in the Intelligence Unit of the Caucasian Military District Staff and was appointed as Soltan Ahmad Mirza's, the later Ahmad Shah Qajar's personal tutor (1907-14). He participated in World War I and after the Russian Civil War he worked as an interpreter in the Bolsheviks' Army in the Caucasus. In the 1920s-30s he worked as a research associate in the Academy of Sciences of Georgia before he was repressed in 1938 (Ia. V. Vasil'kov and M. Iu. Sorokina, eds., Bibliograficheskii slovar'vostokovedov-zhertv politicheskogo terror v sovetskii period, 1917-1991 (St. Petersburg, 2003)).

${ }^{65}$ GNCM, f. 39 (K.N. Smirnov's Private Collection), d. 11 (Diaries, 1907), 1. 18, 21; d. 12 (Diaries, 1909), 1. 43ob.-46; d. 13 (Diaries, 1910), 1. 26ob.-27, 95-6, 142.

${ }^{66}$ Ibid., d. 13 (Diaries, 1909), 1. 4ob.

${ }^{67}$ See Evgenii Belozerskii, "Pis'ma iz Persii ot Baku do Ispagani, 1885-1886," Sbornik geographicheskikh, topographicheskikh $i$ statesticheskikh materialov po Azii 25 (1887): 1-108.

${ }^{68}$ See Fedor Dostoevskii, Dnevnik pisatelia, 1881, http://az.lib.ru/d/dostoewskij_f_m/text_0530. shtml (accessed August 21, 2012). 
against Armenians in Persia. In 1897 he even mentioned that he allocated part of his flat in Tehran to an Armenian asylum-seeking family of six. ${ }^{69}$ It should also be noted that from 1909 to 1919 Russian troops under the command of Generals VorontsovDashkov, Iudenich, Baratov and Bicherakhov, and Colonel Shkuro, at different times, openly and repeatedly defended the Christian population against Turks and Kurds in the western and northwestern parts of Persia. ${ }^{70}$ The above-mentioned discursive component also appeared in the reports and travelogues of other Russian military officers, which were given scrupulous study in a seminal work, Russia and Iran in the Great Game: Travelogues and Orientalism by Elena Andreeva. ${ }^{71}$ Simultaneously, there was another vigorous discourse among the Russian scholars of the time which was passed on to their military disciples and enhanced by the underpinnings of Russkoe Delo, namely the belief in the greater capability of Russian culture, in comparison with the West, to interact with the Orient because of Russia's immediate geographical and, hence, cultural proximity to the latter. ${ }^{72}$ In 1910 , the head of the staff of the Second Cossack Composite Division, Colonel Snesarev, wrote that the Russians were more merciful and beneficent towards the conquered Orientals because of the absence of any striking differences between them and the Russians. This was in contrast to British colonialism, where these differences resulted in cruel and humiliating British treatment of the Orientals. ${ }^{73}$ The point here is not that the Russians were more merciful and noble than the British. Snesarev, Tumanskii, Smirnov and other military Orientologists were trained and subsequently influenced by Rozen and his disciples. Hence, like their "civilian" teachers, officers-vostochniki perceived of Russia "as a particular kind of political and cultural

\footnotetext{
${ }^{69}$ RGVIA, f. 446, op. 1, d. 48 (Kosagovskii's Reports on Trips around Persia and Kurdistan to the Military-Learned Committee), 1. 48-51.

${ }^{70}$ The Archive of Foreign Policy of the Russian Federation, f. 94 "The Secret Cryptographic Section on Iran," op. 2, d. 2, papka 1, 1. 3ob. See also Father Superior Aleksandr (Zarkeshev), Russkaia Pravoslavnaia Tserkov'v Persii-Irane (1597-2001) (St. Petersburg, 2002), 110-15; Aleksandr Shishov, Persidskii front (1909-1918) (Moscow, 2010). In this sense, the research, conducted in 1998-2001 by the Father Superior of St. Nicolas Church in Tehran Aleksandr (Zarkeshev), is worth mentioning. The author made significant efforts in order to reconstruct the history of Russian religious missions to Persia from the reign of the Shah Abbas I (1587-99) to now with the help of the archives of AVPRI, scattered fragments of documents related to missionary activities and the reminiscences of the Russian residents of advanced age in Iran. It resulted in publishing a book, containing, for example, the details of General Baratov troops' interaction with Persian population in 1915-17 or the devastation of the Orumiyeh Orthodox Mission and the massacre of the Assyrian Christians by Turks and Kurds after the evacuation of Russian troops. Although the work is not devoid of self-serving discursive connotation concerning the superiority of the Orthodox Christianity towards Islam and of all things Russian towards the Persian and, in this sense, could be placed in one row with the militant "anti-Islamic" works of famous Russian clerical scholars such as Il'minskii, Ostroumov and Mashanov, it still remains the only relatively comprehensive though rather brief research on the history of the Russian Orthodox Church in Persia/ Iran.

${ }^{71}$ See Andreeva, Russia and Iran.

${ }^{72}$ See Tolz, Russia's Own Orient, 5, 30.

${ }^{73} \mathrm{AV}$, f. 115 , op. 1, d. 70, 1. 5-6 (manuscript of Snesarev's article "Attitudes toward the Asiatic World").
} 
space where there was no boundary between the 'East' and the 'West'."74 As Andrew Wachtel points out, "members of the Russian cultural elite proposed a model that emphasised their nation's peculiar spongelike ability to absorb the best that other peoples had to offer as the basis for a universal, inclusive national culture." 75 In support of Morrison's dictum about the eventual use of Orientological knowledge by states, it should be mentioned that such a discourse eventually turned out to serve domestic needs as "a novel interpretation of the imperial project as a project of translation of world culture into and through Russia" and occupied its intrinsic place within a more general discourse of Russkoe Delo, embracing the promotion of Russian interests and culture in the remote regions crucial for the viability of Russia. ${ }^{76}$ Since the second half of the nineteenth century such regions in the East were Central Asia and Persia where, in case of Russia's hypothetical political and military inertness, the cession of the latter to the British would have provided the eventual forfeit of the former. ${ }^{77}$

Thus, it is possible to discern three main factors which provided the enhanced production of Orientological knowledge by the Russian military during the period in question. The first is the reforms which took place in Russian society in the 1860s-1870s and closely involved the War Ministry. The second is the overwhelming political and military importance of the region which led to the enhanced involvement of the Russian military. And, finally, the third is the compound of multiple sophisticated discursive components, widespread among the educated sectors of Russian society at the time. Of course, the inherent straightforward nature of the military domain simplified this sophistication to a certain extent. In a military context the main discursive components included: (a) the trivial European "Orientalist civilizing mission," passed through the sieve of Russia's alleged receptive interaction with the Orient; (b) the protection of Russian interests versus Western powers; and (c) the promotion of all things Russian, including its own scholarship. The latter was patriotically seen as being "for the benefit of the native land" in its rivalry with the West.

Hence, in response to Engelstein's thesis and further to the debate on Russian Orientalism, by way of example of one of the Russian Orientological domains, this article has revealed the presence of the same interplay of discourses and power relations that is inherent to so-called conventional European societies. However, in the Russian case, this interplay also contained a significant amount of national specificity, implying an uneasy cultural "triptych" embracing the West, Russia and the

\footnotetext{
${ }^{74}$ Tolz, Russia's Own Orient, 5. The term vostochniki derives from Vostok ("the East" or "the Orient" in Russian) and officially was used in late Imperial Russia for differentiating the military officers and the employees of the Ministry for Foreign Affairs from their colleagues who had not received the appropriate Oriental studies training. It can be translated as "Orientalist." Since the early 1920 s a term vostokoved ("Orientologist") has officially been used for everyone professionally trained in Oriental studies. The latter sounds more scholarly in Russian.

${ }^{75}$ Andrew Wachtel, "Translation, Imperialism, and National Self-Definition in Russia," Public Culture 11, no. 1 (1999): 52.

${ }^{76}$ Ibid.

${ }^{77}$ RGVIA, f. 846, d. 18296, 1. 1ob.-20 (Analytical Note to the War Minister).
} 
Orient instead of the generally accepted civilizational dichotomy of "East and West."78 Simultaneously, it should be noted that the participants of the above-mentioned debate on Russian Orientalism agree that Said's concept of "Orientalism is definitely relevant for Russia, insofar as it describes power relations in a concrete imperial/colonial context." ${ }^{79}$ However, it is clear that the whole debate whirls mainly around Said's eponymous model of the two-vector relations between knowledge and state power, whereas the gist is in manifold multi-vector relations of power/knowledge nexus where power is exerted by all agents of this interplay towards each other: scholars, experts, institutions, discourses, state and knowledge itself. Unfortunately, Knight's attempt to break away from this narrow circle of Said's model and to return to the origins of the Foucauldian one remained mostly unnoticed by the others. ${ }^{80}$ It was only about ten years later that the debate was crucially developed by Tolz and Schimmelpenninck, who, leaving behind Said's Orientalism, succeeded in dissecting Russia's Orientological scholarship, highlighting some of its main domains and discourses which demonstrated the very variety of power/knowledge relations therein.

Thus, aiming to contribute to this debate, the article has sought not to confine itself to examining the usual downright vector from state to knowledge but rather to trace back some components of the Foucauldian model. In the given case, this is reciprocal productive multi-vector interaction between the knowledge, chasing new resources for self-reproduction and endowing its agents with new capacities, and the state, represented by its own practices, institutions and individuals. All these are Foucault's very equipotent "vehicles of power." ${ }^{\prime 1}$ Even looking at the military domain, with its lower levels of intellectual sophistication and cognitive autonomy of the individuals and institutions involved, in comparison with the other three domains of Russia's Oriental studies, this reciprocal nexus becomes obvious. The hereby identified product of this nexus is, thus, even more striking. Military scholars such as Kosagovskii, Tumanskii, Smirnov and Snesarev acted in an identical way, as did scholars from other domains (Knight's Grigor'ev, Khalid's Ostroumov, Tolz's Bartol'd and many others). Regardless of whether their influence on state policies was successful or unsuccessful, they all did the following enthusiastically and productively. They exploited those capacities with which they were endowed within the grid of power relations (their training, missions, authorities, connections, their discursive drive for scholarly research, etc.), for the eventual advancement of knowledge itself, in the given case -Persian studies.

\footnotetext{
${ }^{78}$ The term goes back to the expression an awkward triptych coined by Nathaniel Knight in this context (see Knight, "Response to Khalid," 707).

${ }^{79}$ Todorova, "Russian Soul," 720.

${ }^{80}$ See Knight, “Grigor'ev,” 100.

${ }^{81}$ Michel Foucault, "Two Lectures," in Power/Knowledge, ed. C. Gordon (Brighton: Harvester, 1980), 98. See also Jon Simons, Foucault and the Political (London, 1995), 82; Mills, Foucault, 33, 58; and Krementsov, Stalinist Science, 4-5, 29-30.
} 